\title{
Two-dimensional reactive transport modelling for waste management - aquifer injection case study
}

\author{
M Landers Klohn Crippen Berger Ltd., Australia \\ B Usher Klohn Crippen Berger Ltd., Australia \\ D Faulkner Klohn Crippen Berger Ltd., Australia
}

\begin{abstract}
Mine closure projects are increasingly including consideration of detailed groundwater contaminant models that require inclusion of geochemical conditions, attenuation and plume development. To illustrate these concepts, modelling of a proposed borehole mining (BHM) trial, undertaken as part of a mineral sands development project, is provided as a case study. The BHM trial tests a proposed unconventional mining method, known as borehole mining, and trials the selective in situ removal of ore to reduce the need for overburden removal.

The ore is located within an aquifer which resides below the groundwater table and is associated with potentially acid forming (PAF) material. The BHM trial will extract mineralised sands/ore and separate fines $(<53 \mu \mathrm{m})$ from the sands. As part of the $\mathrm{BHM}$ trial, the fines, neutralised with excess limestone $\left(\mathrm{CaCO}_{3}\right)$, and a portion of the ore will be re-injected (with groundwater; 70/30, liquid/solids) back into the cavity space left from extraction.

Klohn Crippen Berger was commissioned to determine the likely water qualities resulting from the various scenarios of the borehole re-injection trial. This was assessed using the results of in-field, laboratory geochemical testing and hydrogeochemical modelling. The hydrogeochemical modelling was undertaken using the Geochemist's Workbench (Bethke \& Yeakel 2010) X2t module (2D reactive transport modelling). The models have incorporated the injectate composition ( 70\% groundwater and $\sim 30 \%$ waste materials), aquifer water quality and simplified aquifer mineralogy. Aquifer hydraulic properties were included based on previous hydrogeological characterisation and groundwater modelling investigations.

A series of $2 D$ reactive transport models were constructed to simulate two injection options and to undertake sensitivity analysis. This includes aquifer injection for a 5-day period (fines only) and 36-day period (fines and ore), followed by one year of migration under natural groundwater gradients. The purpose of the modelling is to provide confidence in the BHM trial, with the possibility of the results being used to assess contaminant trigger values from the point of injection. Resulting water qualities for the various scenarios were compared to Australian drinking water requirements to provide guidance on the preferred injection methodology, and to assess whether the proposed approach would result in significant water quality impacts in the receiving aquifer. The paper uses this case study to illustrate how reactive transport modelling can assist in mine close assessments.
\end{abstract}

\section{Introduction}

A key consideration in assessing likely post-closure impacts is the long-term persistence of contaminant plumes. In many assessments, an ultra-conservative approach is followed with the transport properties of many of the most problematic elements, such as heavy metals, not considered or poorly accounted for. Use of reactive transport models allows mining companies to obtain a more robust indication of the likely chemical concentrations and loads at downstream receptors and to gain an understanding of how these may change over time. 
Consideration of the attenuation of metals is a well-established process in many jurisdictions (e.g. US EPA 2007; NEPC 2013). Inclusion of attenuation directly feeds into the risk-assessment framework for consideration of post-mining impacts. The extent and persistence of the contaminant plume would be driven by the aquifer's flow and biogeochemical conditions, e.g. pH, redox state, minerals, organic matter, microbial conditions, impacted by chemical reactions between the injected by-product, i.e. $70 \%$ groundwater and $\sim 30 \%$ waste materials, and the receptor itself, i.e. solid and liquid phase of the aquifer, and the changes that may occur over the duration of the plume development. These reactions can occur between the plume and the aquifer water, and between the plume and the aquifer minerals. In addition, sorption of key metals of concern to clays, organic matter or iron (oxy) hydroxides can act to attenuate both trace metals and metalloids. The role of reactive transport modelling for this is that all of these mechanisms can be altered by changes to $\mathrm{pH}$, redox and consumption of neutralisation in the aquifer or exceeding the available sorptive capacity of the aquifer. Reactive transport modelling provides a means to evaluate these in a more quantitative manner so that the concentrations and loads that are used to assess the risks can be assessed and presented in manner that considers the temporal changes and is based on the most likely geochemical behaviour of each contaminant of concern.

By applying this approach, the results of the reactive transport model can contextualise the risks and, in many cases, reduce the financial liability, while at the same time providing a basis for operational decision-makers and regulators to accept the groundwater quality risks. In addition, the impact of alternative mitigation strategies can be assessed, which is particularly important in situations where the receptor risk is deemed to be unacceptable in post-closure.

A case study is discussed in this paper to provide an example of how 2D reactive transport modelling may be used as a tool for the management of mine waste at closure. The client is considering using borehole mining (BHM) as part of a mineral sands development project. The BHM trial is proposed to test an unconventional mining method, known as borehole mining, for selective in situ removal of ore from depth $(\sim 60 \mathrm{~m})$, avoiding the need for overburden removal. The ore is located within a shallow aquifer (Figure 1). The BHM trial is proposed to extract mineralised sands/ore $(\sim 20,000$ tonnes) and separate fines $(\sim 1,400$ tonnes; $<53 \mu \mathrm{m})$ from the sands, i.e. the trial will not extract heavy mineral product. Fines will report to a thickener where flocculent will be added to create a thickened fines by-product stream (thickener underflow). The fines and coarse mineralised sand (ore) will be kept at site and neutralised with excess limestone (calcite; $\mathrm{CaCO}_{3}$ ). As part of the BHM trial, the fines and a portion of the ore will be re-injected (with groundwater; 70/30, liquid/solids) back into the cavity space left from extraction. Therefore, two scenarios may occur:

- Scenario 1: injection of fines (1,400 t) only and groundwater ( $70 \%$ liquid) into void space.

- Scenario 2 : injection of fines $(1,400 \mathrm{t})$, ore $(8,600 \mathrm{t})$ and groundwater (70\% liquid) into void space.

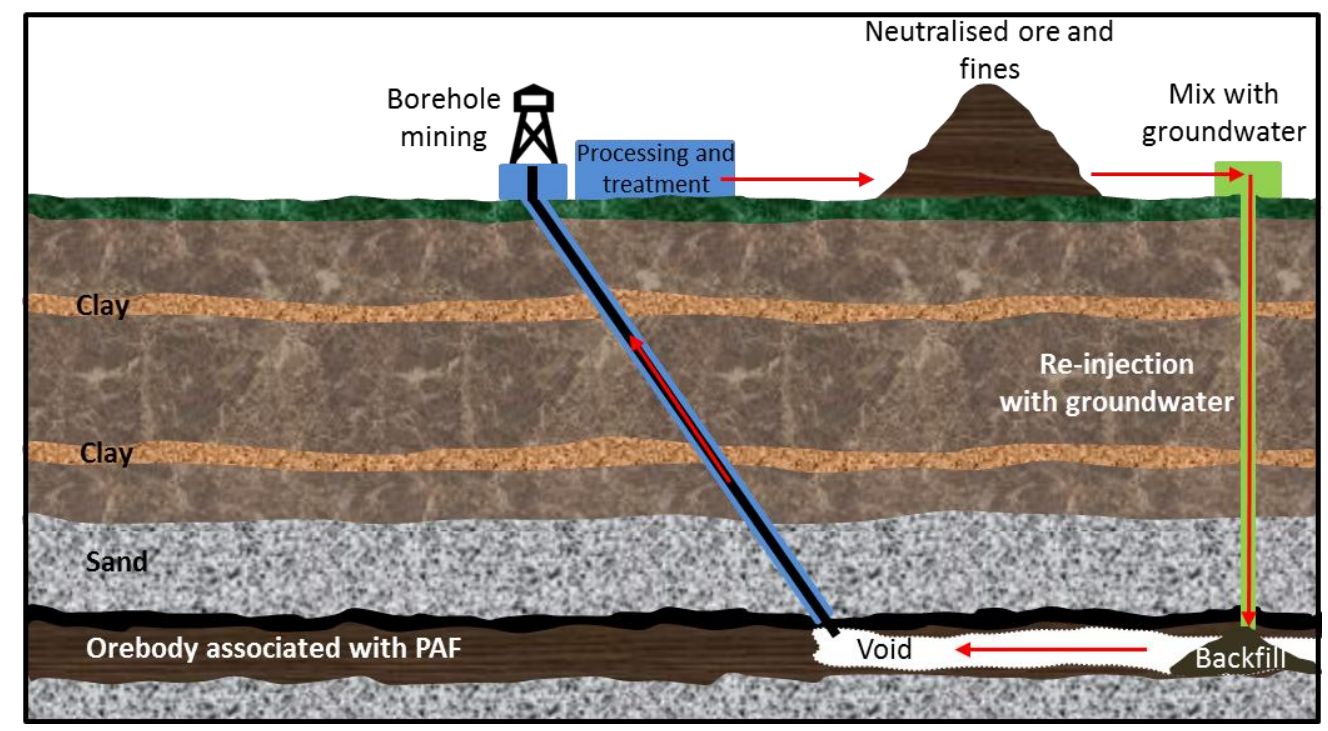

Figure 1 BHM trial conceptual design 
Reactive transport modelling of these scenarios allows the extent and persistence of the contaminant plumes to be assessed and compared to regulatory guidelines.

\section{$2 \quad$ Methods}

\subsection{Aquifer properties}

The ore zone is in an aquifer which is approximately $10 \mathrm{~m}$ above the base of the formation (Figure 1). Through the deposit the formation ranges in thickness from 40 to $60 \mathrm{~m}$ and is fully saturated throughout. Lithological interpretation from cuttings obtained in a drill program indicate the formation comprises sub-angular to sub-rounded, generally poorly graded, fine grained sand with some horizons of coarser grained sand. Thin bands of clay and sandy clay are interspersed. The ore zone consists of a horizon of dark grey, fine to medium grained sand. The ore and overlying organic horizon is characterised as being potentially acid forming (PAF) and associated with elevated metal contents.

The initial conditions of the aquifer is estimated to have a horizontal hydraulic conductivity of $4.4 \mathrm{~m} /$ day and specific storage of $5 \times 10^{-6}$ for the aquifer (Table 1). These parameters are based on field investigations, comparisons with previous studies and using the PEST automatic calibration software for calibration of the site groundwater flow model. Based on site data and hydraulic gradient obtained from two borehole measurements, the specific discharge (flow velocity) was calculated to be $0.4 \mathrm{~m} /$ day (Table 1 ).

\section{Table 1 Key model parameters}

\begin{tabular}{ll}
\hline Parameter & Description \\
\hline Injection rate & $30 \mathrm{~m}^{3} /$ hour \\
\hline Injection time (scenario 1) & 5 days (1,400 t of fines and 3,266 t of $\left.\mathrm{H}_{2} \mathrm{O}\right)$ \\
\hline Injection time (scenario 2) & 36.5 days $\left(1,400\right.$ t of fines, 8,600 t ore and 23,333 t of $\left.\mathrm{H}_{2} \mathrm{O}\right)$ \\
\hline Hydraulic gradient & 0.09 \\
\hline Hydraulic conductivity & $5.09 \mathrm{e}-05 \mathrm{~m} / \mathrm{s}$ or $4.4 \mathrm{~m} /$ day \\
\hline Specific discharge & $4.17 \mathrm{e}-06 \mathrm{~m} / \mathrm{s}$ or $0.4 \mathrm{~m} /$ day \\
\hline Injectate density & $3.5 \mathrm{~g} / \mathrm{cm}^{3}$ \\
\hline Aquifer height $(\mathrm{z}-)$ & $50 \mathrm{~m}$ \\
\hline Porosity & $10-30 \%$ \\
\hline
\end{tabular}

The porosity of the aquifer is suggested to be $\sim 10 \%$, which is particularly low considering the aquifer materials are composed mostly of fine, coarse grained sands. Other reports in the region suggest the porosity may be as high as $38-58 \%$. Since there is a large range of porosities mentioned, several iterations of the models were run with a range of porosities between 10 and 30\% (Table 1). After injection, the models allow the porosity to change due to dissolution and precipitation of minerals.

The groundwater quality results prior to injection are summarised in Table 2 . These indicate that the groundwater is saline with average total dissolved solids (TDS) of $30,000 \mathrm{mg} / \mathrm{L}$ corresponding to saline/supersaline conditions. The average $\mathrm{pH}$ is 7.0 (neutral). Major ions include chloride $\left(\mathrm{Cl}^{-}\right)$, sodium $\left(\mathrm{Na}^{2+}\right)$, sulphate $\left(\mathrm{SO}_{4}{ }^{2-}\right)$, magnesium $(\mathrm{Mg})$, calcium $\left(\mathrm{Ca}^{2+}\right)$ and bicarbonate $\left(\mathrm{HCO}_{3}{ }^{-}\right)$, with lesser potassium $\left(\mathrm{K}^{+}\right)$and silica $\left(\mathrm{SiO}_{2}\right)$ (from highest concentration to lowest). The natural composition of the aquifer groundwater exceeds both the Australian drinking water requirements (NHMRC 2011) and the Australian and New Zealand Environment and Conservation Council (ANZECC) Guidelines (95\% species protection level) (ANZECC 2000) for $\mathrm{SO}_{4}{ }^{2-}, \mathrm{Ca}_{4}{ }^{2+}, \mathrm{Cu}^{+}, \mathrm{Mn}^{3+}$ and $\mathrm{Zn}_{4}{ }^{2+}$. 
Table 2 Groundwater composition for select parameters

\begin{tabular}{|c|c|c|}
\hline Chemical parameter $(\mathrm{mg} / \mathrm{L})$ & Average & Median \\
\hline $\mathrm{pH}$ value & 7.03 & 7.06 \\
\hline Total dissolved solids & 30,737 & 35,750 \\
\hline Silicon as $\mathrm{SiO}_{2}$ & 11.8 & 12.3 \\
\hline Total alkalinity as $\mathrm{CaCO}_{3}$ & 396 & 389 \\
\hline Sulphate as $\mathrm{SO}_{4}$ & 3,291 & 3,820 \\
\hline Chloride & 15,760 & 17,400 \\
\hline Calcium & 526 & 623 \\
\hline Magnesium & 1,211 & 1,460 \\
\hline Sodium & 9,432 & 10,600 \\
\hline Potassium & 35 & 36.5 \\
\hline Ferrous iron & 1.38 & 1.53 \\
\hline Copper & 0.01 & 0.011 \\
\hline Lead & 0.001 & 0.001 \\
\hline Molybdenum & 0.0014 & 0.001 \\
\hline Nickel & 0.0016 & 0.002 \\
\hline Strontium & 13.7 & 14.5 \\
\hline Titanium & 0.013 & 0.01 \\
\hline Zinc & 0.099 & 0.096 \\
\hline Aluminium & 0.2 & 0.095 \\
\hline Arsenic & 0.0025 & 0.0025 \\
\hline Chromium & 0.003 & 0.003 \\
\hline Manganese & 0.45 & 0.49 \\
\hline Redox (pe) & \multicolumn{2}{|c|}{$\sim 4$ (slightly oxidising) } \\
\hline
\end{tabular}

There are limited mineralogical data for the aquifer. The mineralogy is dominated by quartz (33-97\%) and muscovite ( 0-38\%) with a few instances where subordinate Illite, kaolinite, zircon, ilmenite, rutile, iron oxides and birnessite are present. All minerals, excluding quartz and muscovite, were generally present in trace quantities. For simplification of the models, only $\sim 95 \%$ of quartz, $\sim 5 \%$ of muscovite and $0.05 \%$ of pyrite were included as aquifer minerals. Pyrite was not within the detection limits of X-ray Diffraction (XRD; 1\%).

\subsection{Injectate composition}

There are two different scenarios for which the injectate composition will change. The scenarios include the injection of:

- Neutralised fines component only $(1,400 \mathrm{t}$ ), which is mixed with groundwater (aquifer water quality). 
- Neutralised fines component $(1,400 \mathrm{t})$ together with a neutralised ore component $(8,600 \mathrm{t})$, which are mixed with groundwater.

The composition of the solid state for each of the scenarios is displayed in Table 3. For modelling purposes a conservative species was included to assess the likely transport of the injectate and to act as a tracer in the simulations. For this a $1,000 \mathrm{~kg}$ bromide $(\mathrm{Br})$ slug was selected and added as an input tracer to the injectate so the injection progress could be tracked. Prior to injection, an approximate $30 \% / 70 \%$ (by weight) solid/liquid mixture was created using groundwater quality and fines properties; this corresponds to approximately 3,200 and 23,300 t of water for the fines and fines plus ore scenarios, respectively. As a result of the hypersaline groundwater composition, the load contributed by groundwater in the injectate is high (Table 3).

Table 3 Injectate composition (neutralised solids and groundwater components combined) for scenarios 1 and 2

\begin{tabular}{|c|c|c|}
\hline Chemical parameter & Fines composition (kg) & Fines + ore composition $(\mathrm{kg})$ \\
\hline $\mathrm{H}_{2} \mathrm{O}$ & $3,266,000$ & $23,332,000$ \\
\hline $\mathrm{SiO}_{2}(\mathrm{aq})$ & 38.56 & 236 \\
\hline $\mathrm{HCO}_{3}^{-}$ & 929,633 & $6,187,446$ \\
\hline $\mathrm{SO}_{4}^{--}$ & 18,087 & 83,060 \\
\hline $\mathrm{Cl}-$ & 55,948 & 327,691 \\
\hline $\mathrm{Ca}^{++}$ & 613,938 & $4,072,235$ \\
\hline $\mathrm{Mg}^{++}$ & 4,467 & 25,428 \\
\hline $\mathrm{Na}^{+}$ & 33,360 & 198,758 \\
\hline $\mathrm{K}^{+}$ & 116 & 718 \\
\hline $\mathrm{Fe}^{++}$ & 2,147 & 3,363 \\
\hline $\mathrm{Al}^{+++}$ & 104 & 119 \\
\hline $\mathrm{As}(\mathrm{OH})_{4}^{-}$ & 0.09 & 0.18 \\
\hline $\mathrm{Cr}^{+++}$ & 0.51 & 1.67 \\
\hline $\mathrm{Cu}^{+}$ & 0.05 & 0.40 \\
\hline $\mathrm{Pb}^{++}$ & 0.023 & 0.092 \\
\hline $\mathrm{Ni}^{++}$ & 1.30 & 2.31 \\
\hline $\mathrm{Sr}^{++}$ & 53 & 285 \\
\hline $\mathrm{Zn}^{++}$ & 21 & 30 \\
\hline $\mathrm{Br}^{*}$ & 1,000 & 1,000 \\
\hline $\mathrm{U}^{++++}$ & 0.28 & 0.51 \\
\hline V & 0.24 & 1.10 \\
\hline $\mathrm{Mn}$ & 2.90 & 15.75 \\
\hline
\end{tabular}

* Br slug added as a tracer to the injectate so the injection progress could be tracked 


\subsection{Conceptual model}

Hydrogeochemical modelling was conducted using the Geochemist's Workbench (GWB) (Bethke \& Yeakel 2010) X2t module (2D reactive transport modelling). The models have incorporated the injectate composition (70\% groundwater and materials), groundwater quality and simplified aquifer minerals (based on XRD results). Aquifer hydraulic properties were taken from previous hydrogeological modelling investigations outlined in Section 2.1.

The X2t GWB models were constructed to simulate the two scenarios with sensitivity analysis. This includes injection for a 5 day period (scenario 1: fines only) and 36 day period (scenario 2: fines and ore), followed by one year of migration under natural groundwater gradients. The injection was calibrated to the hydrogeological injection modelling. The modelling grid was split-up into $30(x)$ by $10(y)$ nodal blocks with the dimensions of each nodal block varying according to proximity to point of injection (Figure 2). The nodal block associated with the injection well is larger ( $40 \times 10 \mathrm{~m}$; representing the void space), followed by a fine grid $(5 \mathrm{~m})$ immediately adjacent to the injection. The grid spacing becomes coarser with distance from the injection target (Figure 2); the grid represents a 4,500 $\mathrm{m}^{2}$ area which sufficiently discretises the model.

\begin{tabular}{|l|l|l|l|l|l|l|l|l|l|l|l|l|l|l|l|l|l|l|l|l|l|l|l|}
\hline & & & & \\
\hline
\end{tabular}

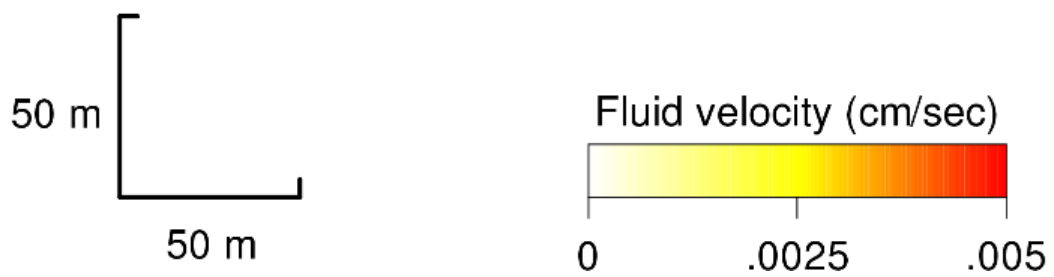

Figure 2 Model nodal grid dimensions and injection fluid velocity. Note: cross-hairs show the location of the injection well

The physical properties of each node were set, e.g. mineralogical assemblage, permeability and porosity, and the rate of injection at the injection bore was set to $30 \mathrm{~m}^{3} /$ day, for 5 days and 36.5 days for the fines and fines + ore, respectively.

The aquifer mineralogical composition was simplified in the models, which included quartz, muscovite (these minerals make up $>90 \%$ of the composition), and a small quantity of pyrite (associated with the ore and overlying organic layer). The rate of reaction of one mineral may differ significantly to another and may be dependent on a number of factors including temperature, surface area and the availability of oxidant and protons. Therefore, a reaction rate law is assigned to each mineral reaction to account for these properties. A rate law for each mineral in the mineralogical assemblage was selected from the literature. Quartz and muscovite were added as kinetic reactions, while pyrite $(0.05 \%)$ was added as a kinetic redox reaction, based on the equation:

$$
\text { Pyrite }\left(\mathrm{FeS}_{2}\right)+3.5^{*} \mathrm{O}_{2}(\mathrm{aq})+\mathrm{H}_{2} \mathrm{O}->\mathrm{Fe}^{++}+2 * \mathrm{SO}_{4}^{--}+2 * \mathrm{H}^{+}
$$

with the reaction rate of pyrite dependent on $\mathrm{pH}$ or $\mathrm{H}^{+}$(protons) and $\mathrm{O}_{2}$ availability

The models allow supersaturated minerals to precipitate and undersaturated minerals to dissolve.

The scenarios can be summarised as:

- Scenario 1: The injectate includes the fines only $(1,400 \mathrm{t})$ and water $(3,266 \mathrm{t})$, which is injected into the aquifer at a rate of $30 \mathrm{~m}^{3} /$ hour for 5 days; this allows for complete injection of the fines. 
The model runs for at least 1 year, with the migration of the plume under modelled aquifer conditions (hydraulic conductivity, hydraulic gradient). The porosity of the aquifer is varied from $10-30 \%$.

- Scenario 2: The injectate includes the fines $(1,400 t)$, ore $(8,600 t)$ and water $(23,333 t)$, which is injected into the aquifer at a rate of $30 \mathrm{~m}^{3} /$ hour for 36.5 days; this allows for complete injection of the fines and ore. The rest of the model is maintained as per scenario 1.

The modelled contaminant plume persistence and water qualities of the aforementioned scenarios are then compared to regulatory guidelines values.

\section{Results and discussion}

The Br slug (or non-reactive slug) was added to the injectate in order to track the migration of the plume flow under modelled aquifer conditions which provides a basis for comparing different scenarios and model sensitivities, e.g. porosity. Individual metals and ions may behave differently to $\mathrm{Br}$; the behaviours of other species are discussed separately in the following sections.

The results for scenario 1 (fines only) and scenario 2 (fines and ore) are shown in Figures 3 and 4, respectively; these scenarios are for an aquifer with $10 \%$ porosity. The results can be summarised in the following points:

- Injection of the materials (scenarios 1 and 2) shows an initially Br plume surrounding the point of injection (injection bore); the $\mathrm{Br}$ concentration is much higher for scenario 2, which reflects the longer injection time (36.5 days) compared to scenario 1 (5 days).

- The injected flow then migrates laterally away from the source. As expected, the plume that migrates away from the source (phase 2) moves much faster for the lower porosity (10\%) simulations than for the higher porosity (30\%) simulations, if the hydraulic conductivities are kept constant and aligned to field values.

- Although the non-reactive $\mathrm{Br}$ plume migrates readily through the aquifer, the majority of metal contaminant plumes are significantly attenuated, e.g. Fe, $\mathrm{Mn}$ and $\mathrm{Cu}$; Figure 5 , and as such do not reach far beyond the point of injection (Table 4). 


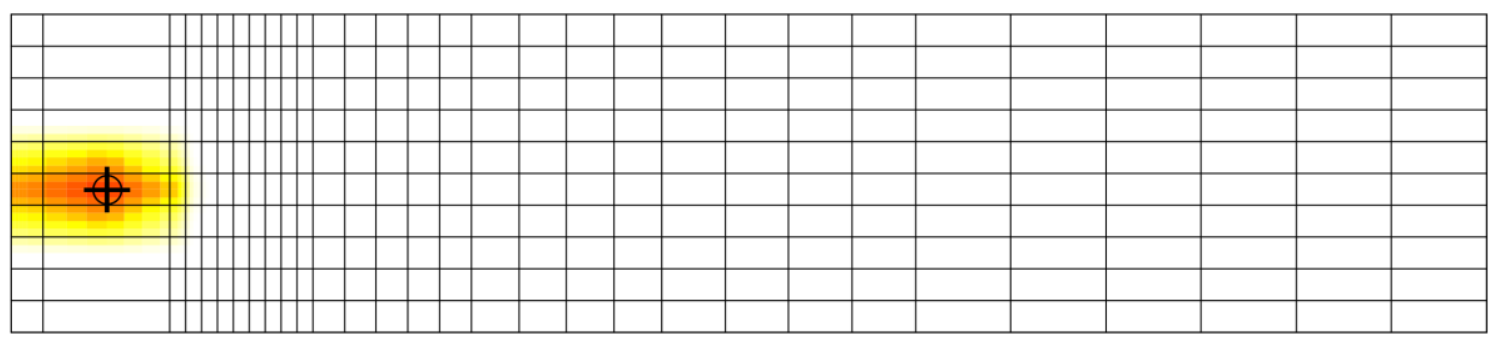

\begin{tabular}{|l|l|l|l|l|l|l|l|l|l|l|l|l|l|l|l|l|l|l|l|l|}
\hline & & & \\
\hline
\end{tabular}
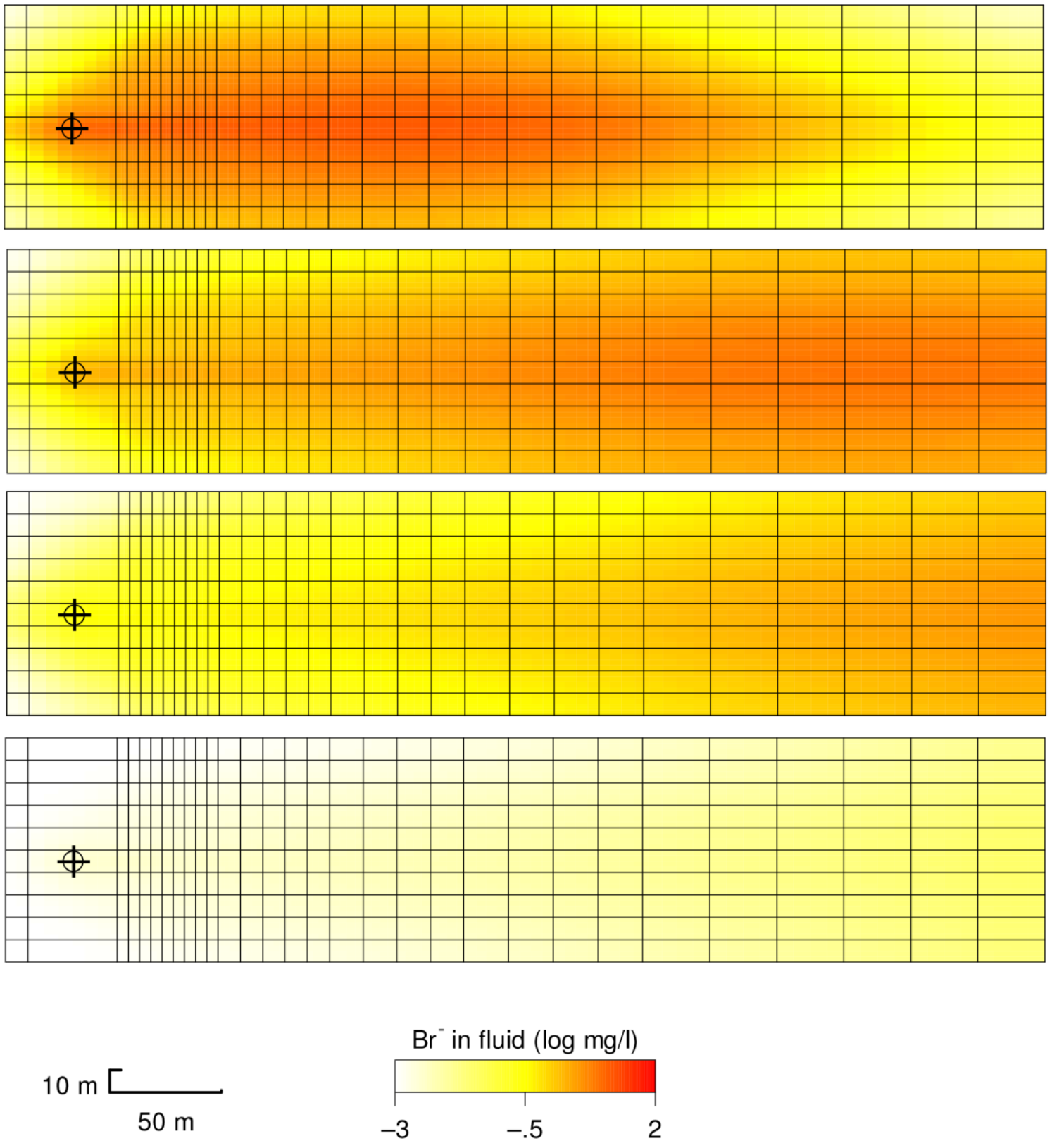

Figure 3 GWB model of $\mathrm{Br}$ slug (1,000 kg) migration through the aquifer: snap-shots from scenario 1; aquifer porosity $=10 \% ; 3$ days, 30 days, 60 days, 120 days, 150 days and 1 year 

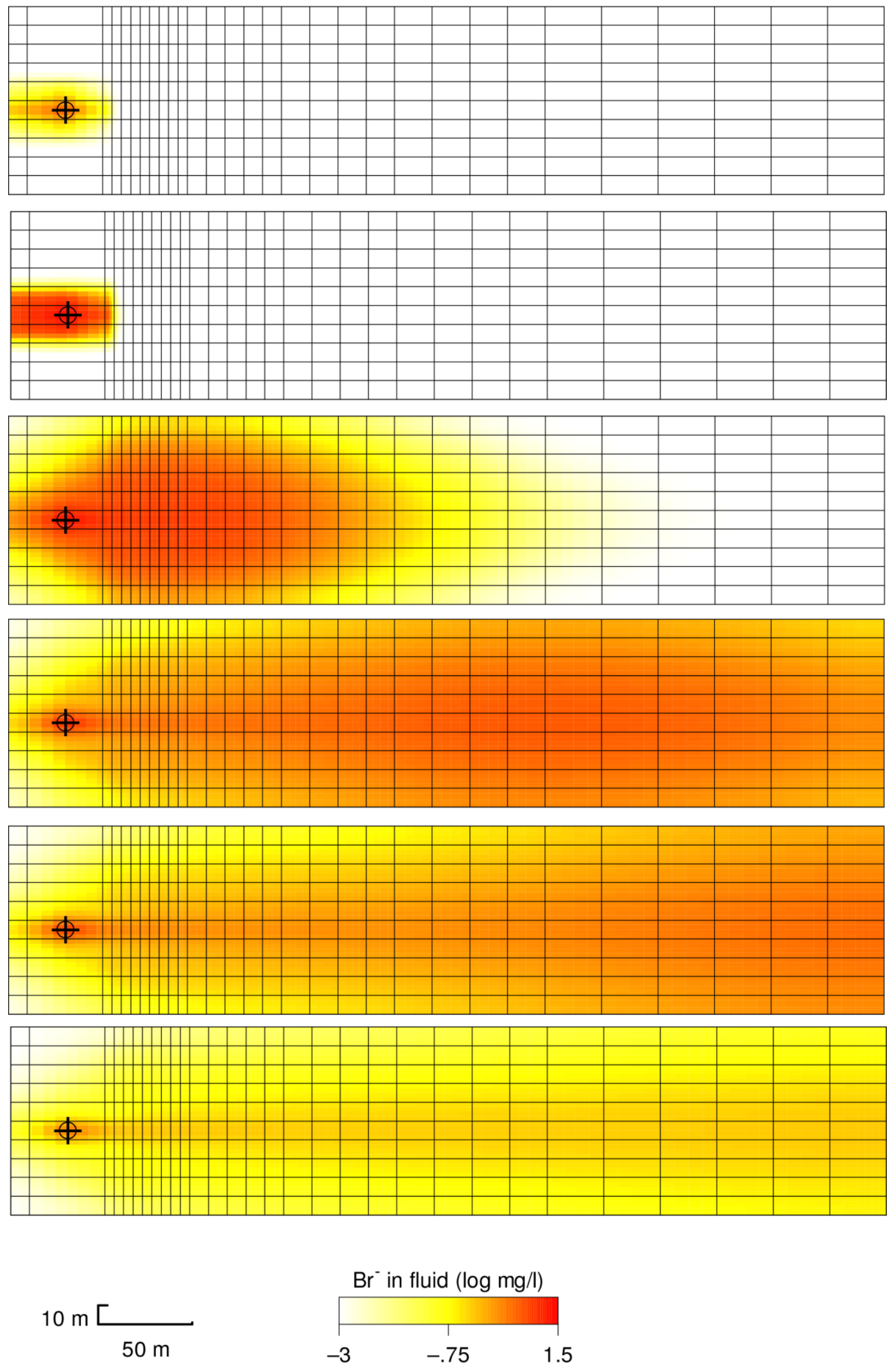

Figure 4 GWB model of $\mathrm{Br}$ slug $(1,000 \mathrm{~kg})$ migration through the aquifer: snap-shots from scenario 2; aquifer porosity $=10 \% ; 3$ days, 30 days, 60 days, 120 days, 150 days and 1 year 


\begin{tabular}{|l|l|l|l|l|l|l|l|l|l|l|l|l|l|l|l|l|l|l|l|l|l|l|l|}
\hline & \\
\hline
\end{tabular}

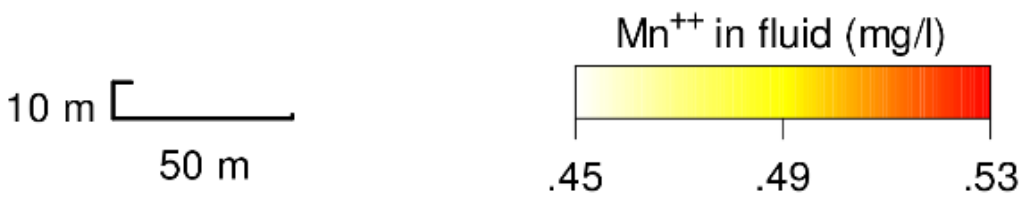

\begin{tabular}{|l|||||||c|c|c|c|c|c|c|c|c|c|c|c|c|c|c|c|}
\hline & \\
\hline
\end{tabular}

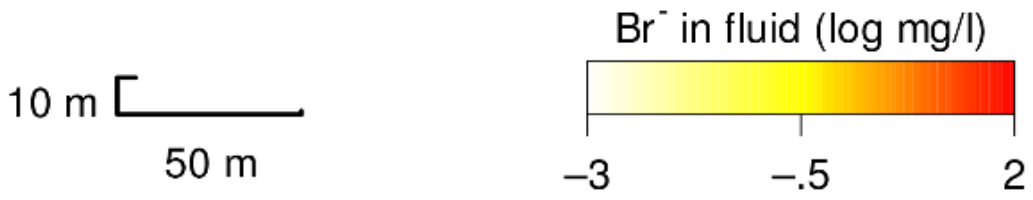

Figure 5 GWB model of $\mathrm{Br}$ slug (top) and $\mathrm{Mn}$ (bottom) migration through the aquifer: snap-shots from scenario 1 ; aquifer porosity $=10 \% ; 60$ days

Due to the high concentration of chemical species in the injectate, there are a number of minerals that are supersaturated and, as such, are likely to precipitate close to the point of injection. Therefore, the chemical species which make up these minerals are depleted in the metal contaminant plume, i.e. they are less mobile in the solid state. The modelling results for selected chemical species are summarised in Table 4 for selected chemical parameters. These key results are further summarised in the following points:

- Injection results in the migration of a plume through the aquifer with a pH of 6.1 compared to the background aquifer $\mathrm{pH}$ of $\sim 6.35$ indicate that the $\mathrm{pH}$ of the modelled area returns to background aquifer conditions within 1 year of injection.

- Although pyrite $\left(\mathrm{FeS}_{2}\right)$ is present within the aquifer composition, i.e. associated with the ore, there is insufficient $\mathrm{O}_{2}$ availability for oxidation to occur (pyrite is present below the water table) and/or there is sufficient alkalinity within the groundwater to buffer any $\mathrm{pH}$ changes.

- Generally the results for scenario 2 are similar to those explained above for scenario 1; however, due to the higher injectate concentrations (and longer injection time), the plume is generally more concentrated and therefore persists at concentrated levels for longer within the aquifer. Similarly, elevated concentrations persist for much longer (or, for $>3$ years) at the point of injection for most of the chemical species; this was not the case for scenario 1 simulations.

- Extending the duration of the trial will be required to ensure that the impacts to the receiving water requirement are as suggested by the initial modelling undertaken for this assessment. 
Table 4 2D reactive transport modelling results for selected chemical parameters for scenarios 1 and 2

\begin{tabular}{|c|c|c|}
\hline $\begin{array}{l}\text { Chemical } \\
\text { parameter }\end{array}$ & Description - scenario 1 & Description - scenario 2 \\
\hline $\mathrm{pH}$ & $\begin{array}{l}\text { Migration of a plume through the aquifer } \\
\text { with a } \mathrm{pH} \sim 6.1 \text { (neutral) compared to the } \\
\text { background aquifer } \mathrm{pH} \text { of } \sim 6.35 \text {, i.e. there } \\
\text { are only minor changes in the aquifer } \mathrm{pH} \text { as a } \\
\text { result of the re-injection. The } \mathrm{pH} \text { of the } \\
\text { modelled area returns to background aquifer } \\
\text { conditions within } 1 \text { year of injection. }\end{array}$ & $\begin{array}{l}\text { Migration of a plume through the aquifer } \\
\text { with a } \mathrm{pH} \sim 6.0 \text { (neutral) compared to the } \\
\text { background aquifer } \mathrm{pH} \text { of } \sim 6.35 \text {, i.e. there } \\
\text { are only minor changes in the aquifer } \mathrm{pH} \\
\text { as a results of the re-injection. A slight } \mathrm{pH} \\
\text { variance persists for several years around } \\
\text { the point of injection. }\end{array}$ \\
\hline $\begin{array}{l}\text { Copper } \\
\text { (Cu) }\end{array}$ & $\begin{array}{l}\text { Moderate Cu concentration within the } \\
\text { aquifer, particularly within close proximity to } \\
\text { the injection bore. There is migration of a } \mathrm{Cu} \\
\text { plume away from the injection bore; } \\
\text { however, the bulk of the metal load remains } \\
\text { within a few metres of the point of injection } \\
\text { due to attenuation. }\end{array}$ & $\begin{array}{l}\text { Moderate Cu concentration within the } \\
\text { aquifer, especially within close proximity } \\
\text { to the injection bore. There is migration of } \\
\text { a Cu plume away from the injection bore; } \\
\text { however, the bulk of the metal load } \\
\text { remains attenuated close to the source. }\end{array}$ \\
\hline $\begin{array}{l}\text { Manganese } \\
\quad(\mathrm{Mn})\end{array}$ & $\begin{array}{l}\text { Migration of a Mn plume which is slightly } \\
\text { more concentrated than the background } \\
\text { aquifer conditions. Plume decreases in } \\
\text { concentration away from the point of } \\
\text { injection and returns to background levels } \\
\text { within < } 1 \text { year. }\end{array}$ & $\begin{array}{l}\text { Some Mn migrates away from the source } \\
\text { with decreasing concentration. The plume } \\
\text { is above regulatory guideline values but } \\
\text { only slightly more concentration than the } \\
\text { background aquifer conditions. There is } \\
\text { also concentration of } \mathrm{Mn} \text { at the point of } \\
\text { injection, which persists for the 3-year } \\
\text { simulation. The background } \mathrm{Mn} \\
\text { concentration exceeds several regulatory } \\
\text { guidelines. }\end{array}$ \\
\hline Zinc $(Z n)$ & $\begin{array}{l}\text { Zn plume migrates away from the point of } \\
\text { injection with time. Initial concentration of } \\
\text { the plume exceeds regulatory guidelines } \\
\text { values for freshwater ecosystems (ANZECC } \\
2000 ; 95 \% \text { protection). Zn concentration } \\
\text { attenuates rapidly away from the point of } \\
\text { injection; however, the plume is above } \\
\text { regulatory guideline values when it migrates } \\
\text { beyond the area modelled (i.e. } 400 \mathrm{~m} \text { ). }\end{array}$ & $\begin{array}{l}\text { Zn plume migrates away from the point of } \\
\text { injection with time. The initial } \\
\text { concentration of the plume (>0.3 mg/L) } \\
\text { exceeds regulatory guidelines values for } \\
\text { freshwater ecosystems (ANZECC 2000; } \\
95 \% \text { Protection); however the } \\
\text { concentration of the plume decreases } \\
\text { away from the point of injection, but is still } \\
\text { above regulatory guideline values when it } \\
\text { migrates beyond the area modelled (i.e. } \\
400 \mathrm{~m} \text { ). The Zn concentration around the } \\
\text { injection bore returns to background } \\
\text { conditions within } 1 \text { year. }\end{array}$ \\
\hline
\end{tabular}




\begin{tabular}{|c|c|c|}
\hline $\begin{array}{l}\text { Chemical } \\
\text { parameter }\end{array}$ & Description - scenario 1 & Description - scenario 2 \\
\hline $\begin{array}{l}\text { Calcium } \\
\text { (Ca) }\end{array}$ & $\begin{array}{l}\text { Very concentrated plume migrates away } \\
\text { from the point of injection with time. } \\
\text { Concentration of } \mathrm{Ca} \text { around the point of } \\
\text { injection remains high (above background } \\
\text { aquifer concentration) for the length of time } \\
\text { of the model runs; this partly reflects the } \\
\text { excess } \mathrm{Ca} \text { available as part of the } \\
\text { neutralisation step before reinjection (added } \\
\text { as lime, } \mathrm{CaCO}_{3} \text { ). }\end{array}$ & $\begin{array}{l}\text { Similar results to Scenario } 1 \text {, albeit the } \\
\text { concentrations are higher for scenario } 2 \text {. }\end{array}$ \\
\hline $\begin{array}{l}\text { Sulphate } \\
\left(\mathrm{SO}_{4}\right)\end{array}$ & $\begin{array}{l}\text { Initially there is a decrease in the } \\
\text { concentration of } \mathrm{SO}_{4} \text { at injection bore; this } \\
\text { reflects the precipitation of gypsum }\left(\mathrm{CaSO}_{4}\right) \\
\text { which is initially supersaturated. As a result } \\
\text { there is an initial } \mathrm{SO}_{4} \text { plume which is below } \\
\text { background aquifer conditions; however, } \\
\text { after } 150 \text { days, the gypsum becomes } \\
\text { undersaturated and dissolves into the } \\
\text { aquifer groundwater where it migrates as a } \\
\text { concentrated plume away from the aquifer. } \\
\text { The second } \mathrm{SO}_{4} \text { plume attenuates rapidly, } \\
\text { and the plume is close to aquifer background } \\
\text { conditions once it reaches the boundary of } \\
\text { the modelling grid ( } 400 \text { m from point of } \\
\text { injection). The aquifer background } \mathrm{SO}_{4} \text { levels } \\
\text { are higher than regulatory guideline values } \\
\text { before reinjection. }\end{array}$ & $\begin{array}{l}\text { Similar to scenario } 1, \mathrm{SO}_{4} \text { groundwater } \\
\text { concentration reflects the precipitation of } \\
\text { gypsum, i.e. the initial concentration of } \\
\mathrm{SO}_{4} \text { is somewhat buffered by gypsum } \\
\text { precipitation. There is an initial } \mathrm{SO}_{4} \text { plume } \\
\text { which is below background groundwater } \\
\text { concentration, followed by a second plume } \\
\text { which is slightly above aquifer background } \\
\text { concentration. The second } \mathrm{SO}_{4} \text { plume } \\
\text { attenuates rapidly. The aquifer background } \\
\mathrm{SO}_{4} \text { levels are higher than regulatory } \\
\text { guideline values before reinjection. }\end{array}$ \\
\hline $\begin{array}{l}\text { Magnesium } \\
\quad(\mathrm{Mg})\end{array}$ & $\begin{array}{l}\text { Behaves similarly to } \mathrm{SO}_{4} \text { with the lower } \\
\text { concentration likely reflecting } \\
\text { supersaturated dolomite }(\mathrm{CaMgCO}) \text {, which } \\
\text { may precipitate in the aquifer; however, } \\
\text { unlike gypsum, dolomite remains } \\
\text { supersaturated over the course of the } \\
\text { simulation. }\end{array}$ & $\begin{array}{l}\text { Behaves similarly as observed in scenario } \\
1 \text {, with the concentration of the plume } \\
\text { below background aquifer conditions, } \\
\text { which reflects supersaturated } \mathrm{Mg} \text { minerals } \\
\text { such as dolomite }\left(\mathrm{CaMgCO}_{3}\right) \text {. }\end{array}$ \\
\hline
\end{tabular}

\section{Conclusion}

This case study has illustrated one potential application of reactive transport modelling to assess potential long-term impacts for an alternate waste disposal method. Several important aspects for the application of this type of modelling for closure planning purposes are provided by this case study. In this case, the major concern was related to the risk of acidification and the potential for metal migration to occur in the aquifer. The reactive transport modelling indicated that, due to the relatively low supply of oxygen and the limited pyrite content, conditions within the re-injected aquifer remain relatively unchanged. The organic carbon overlying the injection zone can also be incorporated into the model to show the scavenging of the oxygen and therefore limit further sulphide oxidation. The neutral conditions, and the high alkalinity of the receiving aquifer, act to further limit the mobility of several of the metals of concern. As illustrated by the modelling results, the rate of migration and the travel distances of many of these metals are greatly attenuated close to the injection. From the perspective of closure risk assessment, these results provide a means to more quantitatively compare alternatives and provide a communication tool to support the geochemical principles 
and understanding of metal migration so that it can be more easily conveyed to stakeholders. An approach occasionally attempted to avoid reactive transport modelling, is to use the ratio between conservative species such as $\mathrm{Cl}$ or $\mathrm{Br}$ and metals of concern. The case has clearly shown the inherent uncertainties introduced by applying such an approach to temporal assessment of impact downstream/at a compliance point.

Finally, the case study has indicated, using a relatively simple hydrogeochemical system, that reactive transport models can be effectively used to assess both closure alternatives and to provide concentration profiles that can be directly explained by the aquifer conditions and the geochemical reactions that occur in migrating plumes.

\subsection{Modelling limitations}

Several knowledge gaps and limitations in the modelling were identified and include:

- The aquifer characteristics used in the model are the initial conditions of the aquifer prior to any leaching process/extraction. The characteristics provide base ground data analyses for the injection of the waste into the aquifer outside the area that will be leached.

- Microbial activity was not taken into account for this modelling. Increasing the injectate dissolved oxygen (DO) concentration is likely to stimulate microbial activity and thus increase the risk of bioclogging. Increasing the amount of dissolved oxygen increases the rate of ferrous to ferric iron conversion and can make the conditions more favourable for both heterotrophic bacteria which can use the available organic carbon and autotrophic bacteria that can gain energy by using oxygen as an electron acceptor. Excessive biomass accumulation in an aquifer may cause bioclogging which can lead to a reduction in porosity with an associated decrease in the aquifer hydraulic conductivity and change in flow regime.

- More detailed consideration of sorption could be included once better spatial discretisation of organic carbon and clay lenses is available. In that respect, the presented modelling results can be regarded as conservative.

- The modelling identified that several minerals may precipitate in the aquifer as a result of the re-injection. This would need to be quantified to investigate the possibility of clogging aquifer pore space.

- Despite these limitations, reactive transport modelling of this case still provided a meaningful conceptualisation of the problem and a framework within which the site conditions, the geochemical controls and the potential impact downstream at receptors or compliance points could be evaluated.

\section{References}

ANZECC (Australian and New Zealand Environment and Conservation Council) 2000, National Water Quality Management Strategy: Australia and New Zealand Guidelines for Fresh and Marine Water Quality, vol. 1, Australian and New Zealand Environment and Conservation Council, Canberra.

Bethke, C \& Yeakel, S 2010, The Geochemist's Workbench: Reaction Modelling Guide, University of Illinois, Colorado, p 92.

NEPC (National Environment Protection Council) 2013, National Environment Protection (Assessment of Site Contamination) Measure 1999, National Environment Protection Council, Canberra.

NHMRC (National Health and Medical Research Council) 2011, National Water Quality Management Strategy: Australian Drinking Water Guidelines 2011, National Health and Medical Research Council, Canberra.

US EPA (United States Environmental Protection Agency) 2007, Monitored Natural Attenuation of Inorganic Contaminants in Ground Water: Technical Basis for Assessment, vol. 1, United States Environmental Protection Agency, Oklahoma. 
